(E-ISSN : 2615-4978, P-ISSN : 2086-4620)

Vol 10 No 1, Maret 2019

\title{
Motivasi, Komitmen Organisasional Dan Kepuasan Kerja Karyawan di Waroeng Spesial Sambal, Jatinangor
}

\author{
Sir Kalifatullah Ermaya ${ }^{1}$ \\ Siti Mujdalipah ${ }^{2}$ \\ ${ }^{1}$ Institut Manajemen Koperasi Indonesia. \\ ${ }^{2}$ Kejuruan Universitas Pendidikan Indonesia. \\ E-mail:kalifatullah86@gmail.com \\ E-mail: siti.mujdalipah@upi.edu
}

\begin{abstract}
ABSTRAK
Industri jasa penyedia makanan mendapatkan banyak tantangan di era disrupsi revolusi industri 4.0 saat ini. Mengingat urgensinya untuk meningkatkan Motivasi dan Komitmen Organisasional yang ada di salah satu Restoran di Jatinangor, maka di dalam penelitian ini di ambil judul "Motivasi, Komitmen Organisasional dan Kepuasan Kerja Karyawan di Waroeng Spesial Sambal, Jatinangor”. Penelitian ini termasuk dalam kategori penelitian asosiatif kausal dengan menggunakan pendekatan kuantitatif. Hasil penelitian menunjukkan: 1. Variabel Motivasi secara parsial berpengaruh secara signifikan terhadap variabel Kepuasan Karyawan; 2. Variabel Komitmen Organisasional secara parsial tidak berpengaruh dan tidak signifikan terhadap variabel Kepuasan Karyawan; 3. Variabel Motivasi dan Komitmen Organisasional secara simultan berpengaruh positif dan signifikan terhadap variabel Kepuasan Karyawan.
\end{abstract}

Kata Kunci: Motivasi, Komitmen Organisasional, Kepuasan Kerja

\begin{abstract}
The food service industry has received many challenges in the current era of disruption of the industrial revolution 4.0. Given the urgency of increasing the Motivation and Organizational Commitment in one of the restaurants in Jatinangor, the title of this study is "Motivation, Organizational Commitment and Job Satisfaction in Waroeng Spesial Sambal, Jatinangor". This research belongs to the category of associative causal research using a quantitative approach. The results showed: 1. Motivation partially has a significant effect on the Employee Satisfaction variable; 2. Organizational Commitment partially has no effect and isn't significant on the Employee Satisfaction variable; 3. Motivation and Organizational Commitment simultaneously have a positive and significant effect on the Employee Satisfaction variable.
\end{abstract}

Keywords: Motivation, Organizational Commitment, Job Satisfaction

\section{PENDAHULUAN}

Manajemen sumber daya manusia merupakan bagian dari ilmu manajemen yang memfokuskan perhatiannya pada pengaturan peranan sumber daya manusia dalam kegiatan suatu organisasi. Dalam mencapai tujuannya tentu suatu organisasi memerlukan sumber daya manusia sebagai pengelola sistem. Agar sistem ini berjalan tentu dalam pengelolaanya harus memperhatikan beberapa aspek penting seperti pelatihan, pengembangan, pemberian motivasi dan aspek-aspek lainnya. Hal ini akan menjadikan manajemen sumber daya manusia sebagai salah satu indikator penting pencapaian tujuan organisasi secara efektif dan efisien.
Persaingan dalam dunia yang kompetitif saat ini, setiap individu berjuang untuk menjadi di depan yang lain dan menciptakan masa depan yang lebih baik bagi diri mereka sendiri. Keberhasilan suatu perusahaan dalam mencapai tujuan tidak terlepas dari peran strategis sumber daya manusia yang dimilikinya, karena sumber daya manusia yang akan mengatur dan mengelola sumber daya lain yang dimiliki perusahaan untuk membantu mewujudkan tujuan perusahaan itu sendiri. Untuk mewujudkan hal tersebut diperlukan sumber daya manusia yang berkualitas agar organisasi memperoleh daya saing sehingga bisa mendapatkan keunggulan kompetitif dan mencapai tujuan perusahaan. 
Di dalam Manajemen Sumber Daya Manusia, Kepuasan kerja karyawan merupakan yang harus dimiliki oleh seluruh karyawan di dalam suatu organisasi. Kepuasan kerja merupakan sebuah perasaan positif terhadap pekerjaan yang dihasilkan dari evaluasi atas karakteristik-karakteristiknya (Robbins, 2015:49). Sehingga dapat dikatakan karyawan yang memiliki rasa kepuasan terhadap pekerjaannya cenderung akan berkinerja lebih baik.

Komitmen organisasional merupakan suatu keadaan yang menunjukkan adanya keterikatan psikologis seorang pegawai pada suatu organisasi untuk loyal dan terlibat dalam organisasi. Semakin loyal seorang pegawai maka semakin tinggi pula komitmen organisasionalnya. Salah satu indikator untuk melihat tingkat kesetiaan pegawai terhadap organisasinya dapat dilihat dari masa kerja pegawai tersebut. Semakin lama masa kerjanya maka semakin tinggi pula rasa setianya terhadap organisasi. Jika pekerja merasa dirinya terikat dengan nilai-nilai organisasional yang ada maka dia akan merasa senang dalam bekerja, sehingga kinerjanya dapat meningkat.

Disamping komitmen organisasional, untuk pencapaian tujuan organisasi ke arah yang lebih baik dibutuhkan motivasi baik secara internal maupun eksternal. Pemberian motivasi kerja eksternal dan internal yang makin baik dapat mendorong karyawan bekerja dengan makin produktif. Dengan produktivitas kerja yang tinggi, ongkos karyawan per unit produksi bahkan akan semakin rendah.

Pertumbuhan ekonomi Indonesia di kuartal II2018 tercatat sebesar 5,27\%. Dari 17 lapangan usaha,

Salah satu industri yang terus berkembang dan dituntut untuk meningkatkan daya saingnya adalah industri jasa kuliner makanan. Dari gambar di atas menunjukkan bahwa jasa kuliner menempati pada urutan pertama dalam Produk Domestik Bruto. Artinya, industri jasa ini memberikan kontribusi yang besar pada pertumbuhan ekonomi di Indonesia. Persaingan di antara jasa kuliner untuk saat ini sangatlah ketat, sebab pemberi seluruhnya tumbuh positif tapi yang tertinggi terjadi di jasa lainnya, jasa perusahaan, dan transportasi

pergudangan (finance.detik.com). Hal ini dibuktikan dengan grafik Pertumbuhan PDB (Produk Domestik Bruto) Sektoral Triwulan II 2018 berikut ini.

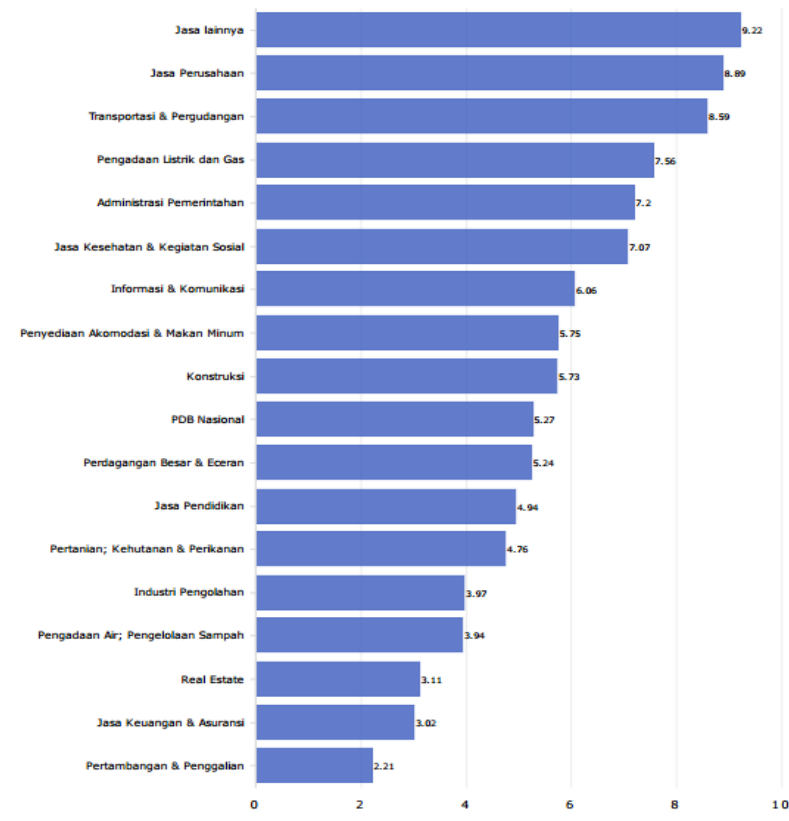

Gambar 1.

\section{Pertumbuhan PDB Sektoral Triwulan II 2018}

(Sumber: databoks.co.id)

jasa ini dituntut untuk memberikan kualitas yang baik, inovatif, kreatif dan berbeda dari yang lainnya.

Waroeng Spesial Sambal (SS) adalah salah satu restoran kuliner yang sedang berkembang di Bandung. Perusahaan pemberi jasa makanan yang sudah berdiri sejak 14 tahun yang lalu ini mempunyai 3400 karyawan Warung dan 322 karyawan manajemen yang tersebar di 9 kantor regional dan 72 Cabang warung di Indonesia.

Tabel 1.

Hasil Penyebaran Kuesioner Pra Riset Tingkat Kepuasan Konsumen Terhadap Pelayanan Waroeng Spesial Sambal

\begin{tabular}{|l|l|c|c|c|c|c|}
\hline NO & INDIKATOR KEPUASAN KONSUMEN & STP & TP & KP & P & SP \\
\hline 1 & Pelayanan & $12,50 \%$ & $17,50 \%$ & $32,50 \%$ & $20,00 \%$ & $17,50 \%$ \\
\hline 2 & Ketepatan Waktu Buka & $12,50 \%$ & $10,00 \%$ & $22,50 \%$ & $37,50 \%$ & $17,50 \%$ \\
\hline 3 & Keramahan & $17,50 \%$ & $20,00 \%$ & $27,50 \%$ & $15,00 \%$ & $20,00 \%$ \\
\hline 4 & Kecepatan Pelayanan & $37,50 \%$ & $22,50 \%$ & $20,00 \%$ & $10,00 \%$ & $10,00 \%$ \\
\hline 5 & Kebersihan Pelayanan & $15,00 \%$ & $20,00 \%$ & $15,00 \%$ & $37,50 \%$ & $12,50 \%$ \\
\hline
\end{tabular}

Keterangan:

$\begin{array}{llll}\text { STP } & \text { Sangat Tidak Puas } & \text { P } & \text { Puas } \\ \text { TP } & \text { Tidak Puas } & \text { SP } & \text { Sangat Puas }\end{array}$

KP Kurang Puas 
Berdasarkan table 1. diatas, tentang kepuasan konsumen terhadap pelayanan dapat dilihat bahwa masih banyaknya konsumen yang tidak puas dengan pelayanan yang diberikan oleh karyawan Waroeng Spesial Sambal. Hasil kuesioner tersebut menunjukkan bahwa merugikan bagi konsumen yang seharusnya mendapatkan pelayanan terbaik. Menurut hasil pra penelitian tersebut, bahwa kepuasan konsumen dipengaruhi kepuasan kerja karyawan Waroeng Spesial Sambal.

Waroeng Spesial Sambal (SS) merupakan salah satu kuliner yang banyak diminati oleh berbagai kalangan, baik mahasiswa maupun masyarakat pada umumnya. Kepuasan kerja bagi karyawan disebuah restauran harus terwujud dan harus dirasakan oleh setiap konsumen yang berinteraksi secara langsung dengan karyawan dalam bentuk suatu pelayanan. Sehingga kepuasan konsumen mencerminkan kepuasan kerja karyawan yang dapat menentukan keberhasilan dalam mencapai tujuan suatu perusahaan.

Tabel 2.

\section{Penyebab Penurunan Pelayanan Karyawan}

1. Karyawan merasa pendapatan perbulannya kurang

2. Tidak adanya bonus

3. Pelayanan dari karyawan menurun ditunjukan dari hasil riset beberapa pelanggan

4. Jam kerja memiliki 2 shift

5. Libur hanya diberikan setiap satu minggu sekali

Berdasarkan tabel 2, maka dapat dilihat menurunnya pelayanan karyawan Waroeng Spesial Sambal terhadap konsumen bisa disebabkan oleh sistem gaji yang diterapkan selama ini. Banyak karyawan yang tidak puas dengan pendapatan perbulannya, apalagi tidak adanya bonus bagi para karyawan. Menurunnya pelayanan karyawan juga disebabkan oleh jam kerja yang terlalu lama setiap harinya sehingga karyawan merasa jenuh dengan pekerjaannya. Menurut penelitian, sistem gaji yang diterapkan bisa mempengaruhi kinerja karyawan sehingga menyebabkan karyawan jenuh hingga terjadi keluarnya para pekerja.

Berdasarkan uraian diatas, maka penulis tertarik untuk melakukan penelitian tentang "Pengaruh
Motivasi Dan Komitmen Organisasional Terhadap Kepuasan Kerja Karyawan" Studi kasus pada Waroeng Spesial Sambal Jatinangor

Berkaitan dengan masalah yang disebutkan diatas, maka tujuan dari penelitian ini antara lain :

1. Mengetahui pengaruh motivasi kerja karyawan secara parsial terhadap kepuasan kerja karyawan di Waroeng Spesial Sambal.

2. Mengetahui pengaruh komitmen organisasional secara parsial terhadap kepuasan kerja karyawan di Waroeng Spesial Sambal.

3. Mengetahui pengaruh motivasi kerja karyawan dan komitmen organisasional secara simultan terhadap kepuasan kerja karyawan di Waroeng Spesial Sambal.

\section{TINJAUAN PUSTAKA}

Penelitian ini mengambil grand theory Manajemen Sumber Daya Manusia. Menurut Dessler (2013:4) Human Resource Management is the process of acquiring, training, appraising and compensating employees and of attending to their labor relations, health and safety and fairness concerns. Sementara itu, middle theory yang digunakan dalam penelitian ini adalah Perilaku Organisasi. Menurut Robbins (2015:5), perilaku organisasi merupakan bidang studi yang menginvestasi pengaruh individu, kelompok, dan struktur terhadap perilaku di dalam organisasi, untuk tujuan penerapan pengetahuan demi peningkatan efektivitas organisasi.

Motivasi merupakan sekelompok faktor yang menyebabkan individu berperilaku dalam cara tertentu (Griffin, 2004:38). Motivasi ini tentu ditunjang pula dengan adanya komitmen organisasional yang merupakan tingkat dimana seorang pekerja mengidentifikasi sebuah organisasi, tujuan dan harapannya untuk tetap menjadi anggota (Robbins, 2015:47). Jewell dan Siegall (1998 :529) menyatakan bahwa kepuasan kerja adalah sikap yang timbul berdasarkan penilaian terhadap situasi kerja. Secara sederhana, kita dapat mengatakan bahwa karyawan yang puas lebih menyukai situasi kerja daripada tidak menyukainya. 


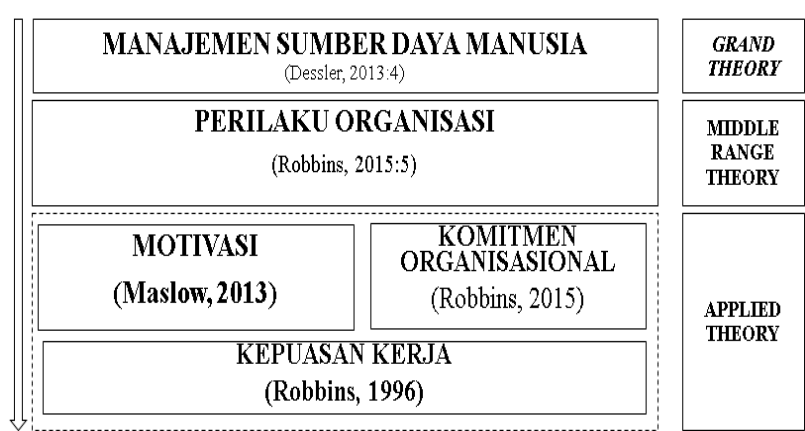

Gambar 2.

Keterkaitan Variabel yang Digunakan dalam Penelitian

\section{Manajemen Sumber Daya Manusia}

Noe et al (2010:5) menyatakan bahwa Manajemen Sumber Daya Manusia (MSDM) merupakan kebijakankebijakan, praktik-praktik, serta sistem-sistem yang yang memengaruhi perilaku, sikap, dan kinerja karyawan. Sementara itu, Byars \& Rue (2004) menyatakan bahwa MSDM merupakan desain aktivitas yang mencakup pengadaan dan pengkoordinasian sumber daya manusia. Sedangkan pengertian Sumber Daya Manusia menurut Jackson dan Schuler (2000) adalah orang yang berbakat dan bersemangat tinggi yang tersedia bagi organisasi sebagai kontributor potensial untuk menciptakan dan merealisasikan tujuan, misi, serta visi organisasi.

\section{Perilaku Organisasi}

Perilaku organisasi (Daft, 2006:258) merupakan sebuah lapangan antardisiplin ilmu yang ditujukan pada studi terhadap sikap-sikap, perilaku, dan kinerja manusia di dalam organisasi. Hal senada dikemukakan oleh Robbins (2015:11-15) yang menyatakan bahwa beberapa tantangan dari Perilaku Organiasi saat ini adalah merespon tekanan ekonomi, merespon globalisasi, mengelola tenaga kerja, meningkatkan kesejahteraan pekerja saat bekerja dan menciptakan lingkungan kerja yang positif. Hal ini jelas terungkap bahwa topik dari penelitian ini yang berhubungan dengan Motivasi Karyawan, Komitmen Organisasional dan Kepuasan Kerja Karyawan merupakan bagian dari ilmu Perilaku Organisasi.

\section{Motivasi}

Menurut Veithzal Rivai (2011:839), motivasi adalah kondisi yang berpengaruh membangkitkan, mengarahkan dan memelihara perilaku yang berhubungan dengan lingkungan kerja. Sedangkan menurut Sadili Samsudin (2006:81), motivasi merupakan kondisi atau energi yang menggerakkan diri karyawan yang terarah atau tertuju untuk mencapai tujuan organisasi perusahaan. Jadi, motivasi kerja adalah suatu kondisi yang menimbulkan dorongan atau membangkitkan semangat kerja seorang karyawan untuk mencapai tujuan perusahaan.

Di dalam literaturnya, variabel motivasi memiliki banyak teori yang berbeda-beda yang muncul dari hasil penelitian dengan organisasi yang berbeda-beda pula. Salah satu teori Motivasi yang terkenal adalah Teori Isi dari Abraham Maslow yang mengemukakan bahwa hierarki kebutuhan manusia adalah sebagai berikut :

1. Kebutuhan fisiologis, yaitu kebutuhan untuk makan, minum, perlindungan fisik, bernafas, seksual. Kebutuhan ini merupakan kebutuhan tingkat terendah atau disebut pula sebagai kebutuhan yang paling dasar.

2. Kebutuhan rasa aman, yaitu kebutuhan akan perlindungan dari ancaman bahaya, pertentangan, dan lingkungan hidup.

3. Kebutuhan untuk rasa memiliki, yaitu kebutuhan untuk diterima oleh kelompok, berafiliasi, berinteraksi, dan kebutuhan untuk mencintai dicintai.

4. Kebutuhan akan harga diri, yaitu kebutuhan untuk dihormati dan dihargai oleh orang lain.

5. Kebutuhan untuk mengaktualisaiskan diri, yaitu kebutuhan untuk menggunakan kemampuan, skill, dan potensi. Kebutuhan untuk berpendapat dengan mengemukakan ide-ide memberi penilaian kritik terhadap sesuatu.

\section{Komitmen Organisasional}

Meyer \& Herscovitch (2001) mengemukakan bahwa komitmen organisasional merupakan sebuah kekuatan yang mengikat seorang individu untuk suatu tindakan yang relevan dengan sebuah target atau lebih. Komitmen organisasional merupakan sikap yang merefleksikan loyalitas karyawan pada organisasi serta proses yang berkelanjutan dimana anggota organisasimengekspresikan rasa kepeduliannya terhadap organisasi (Luthans, $2006: 248$ ). (Widari dan Wibawa, Vol. 6, No. 7, 2017:4363)

Robbins (2011; 100) mengelompokan komitmen organisasi dengan tiga indikator yang terpisah, yaitu :

\section{Komitmen Afektif (Affective Commitment)}

Komitmen afektif merupakan perasaan emosional untuk organisasi dan keyakinan di dalam nilainilainya. Seseorang yang memiliki komitmen afektif yang kuat akan terus bekerja dalam suatu organisasi karena mereka memang ingin melakukan hal tersebut.

2. Komitmen Berkelanjutan (Continuance Commitment) 
Komitmen berkelanjutan merupakan nilai ekonomi yang dirasakan dari bertahan dalam suatu organisasi dibandingkan dengan meninggalkan organisasi tersebut. Seorang karyawan mungkin bertahan dan berkomitmen dengan organisasi dan pemberi kerja karena diberi imbalan yang cukup tinggi. Komitmen ini menyebabkan seorang karyawan bertahan pada suatu organisasi karena mereka membutuhkannya.

\section{Komitmen Normatif (Normative Commitment)}

Komitmen normatif merupakan kewajiban seseorang untuk bertahan di dalam suatu organisasi untuk alasan-alasan moral atau etis. Komitmen ini menyebabkan seorang karyawan bertahan pada suatu pekerjaan karena mereka merasa wajib untuk melakukannya. Dengan kata lain, komitmen normatif ini berkaitan dengan perasaan wajib untuk tetap bekerja dalam sebuah organisasi.

\section{Kepuasan Kerja}

Menurut Luthans (2007), kepuasan kerja karyawan adalah perasaan positif yang terbentuk dari penilaian karyawan terhadap pekerjaannya berdasarkan persepsi karyawan mengenai seberapa baik pekerjaannya, yang berarti bahwa apa yang diperoleh dalam bekerja sudah memenuhi apa yang dianggap penting. Indikator kepuasan kerja menurut Luthans (2007) yaitu: (1) kepuasan terhadap pembayaran gaji atau upah, (2) kepuasan terhadap pekerjaan itu sendiri, (3) kepuasan terhadap rekan kerja, (4) kepuasan terhadap promosi, dan (5) kepuasan terhadap pengawasan kerja (Changgriawan AGORA Vol. 5, No. 3, (2017).
Menurut Masrukhin dan Waridin (2012) kepuasan kerja seorang individu tergantung pada karakteristik individu dan situasi pekerjaan. Setiap individu akan memiliki tingkat kepuasan kerja yang berbeda sesuai dengan kepentingan dan harapan individu tersebut sehingga tingkat kepuasan yang dirasakan semakin tinggi, begitu pula sebaliknya.

Menurut Jewell dan Siegall (1998) beberapa aspek dalam mengukur kepuasaan kerja, diantaranya :

a. Aspek psikologis, berhubungan dengan kejiwaan karyawan meliputi minat, ketentraman kerja, sikap terhadap kerja, bakat dan ketrampilan.

b. Aspek fisik, berhubungan dengan kondisi fisik lingkungan kerja dan kondisi fisik karyawan, meliputi jenis pekerjaan, pengaturan waktu kerja, pengaturan waktu istirahat, keadaan ruangan, suhu udara, penerangan, pertukaran udara, kondisi kesehatan karyawan dan umur.

c. Aspek sosial, berhubungan dengan interaksi sosial, baik antar sesame karyawan dengan atasan maupun antar karyawan yang berbeda jenis kerjanya serta hubungan dengan anggota keluarga.

d. Aspek finansial, berhubungan dengan jaminan serta kesejahteraan karyawan, yang meliputi sistem dan besar gaji, jaminan sosial, tunjangan, fasilitas dan promosi

Tabel 3.

Penelitian Terdahulu yang Terkait dengan Penelitian Ini

\begin{tabular}{|c|c|c|c|c|c|}
\hline No & $\begin{array}{c}\text { Nama dan Tahun } \\
\text { Penelitian }\end{array}$ & Judul Penelitian & Variabel & $\begin{array}{c}\text { Metode } \\
\text { Penelitian }\end{array}$ & Persamaan/Perbedaan \\
\hline 1 & $\begin{array}{l}\text { Widya paramita, } \\
\text { Dianty Larasati, } \\
\text { Agung Wahyu } \\
\text { handaru (2014) }\end{array}$ & $\begin{array}{l}\text { Pengaruh Motivasi dan } \\
\text { Komitmen Organisasional } \\
\text { Terhadap Kepuasan Kerja } \\
\text { Pada Pegawai Tata Usaha }\end{array}$ & $\begin{array}{l}\text { 1. Motivasi } \\
\text { 2. Komitmen } \\
\text { organisasional } \\
\text { 3. Kepuasan kerja }\end{array}$ & $\begin{array}{l}\text { Deskriptif } \\
\text { kuantitatif }\end{array}$ & $\begin{array}{l}\text { Persamaan: variabel yang } \\
\text { diteliti } \\
\text { Perbedaan: Fokus penelitian } \\
\text { dibidang yang berbeda }\end{array}$ \\
\hline 2 & $\begin{array}{l}\text { Vica } \\
\text { Angelia / } \\
2006\end{array}$ & $\begin{array}{l}\text { Pengaruh kepuasan kerja } \\
\text { terhadap komitmen } \\
\text { organisasi karyawan } \\
\text { foodcourt "X "Tunjungan } \\
\text { Plaza Surabaya }\end{array}$ & $\begin{array}{l}\text { 1. Komitmen } \\
\text { karyawan } \\
\text { 2. Kepuasan } \\
\text { kerja }\end{array}$ & $\begin{array}{l}\text { Deskriptif } \\
\text { kuantitatif }\end{array}$ & $\begin{array}{l}\text { Persamaan: variabel yang } \\
\text { diteliti } \\
\text { Perbedaan: Pada } \\
\text { perusahaan yang diteliti }\end{array}$ \\
\hline 3 & $\begin{array}{l}\text { Ari Dwi } \\
\text { Setyawan } \\
/ 2008\end{array}$ & $\begin{array}{l}\text { Pengaruh Komitmen } \\
\text { Organisasi terhadap } \\
\text { Kepuasan Kerja dengan } \\
\text { Motivasi sebagai Variabel } \\
\text { Intmmenninn mndn Vnntnn }\end{array}$ & $\begin{array}{l}\text { 1.Motivasi } \\
\text { 2.Komitmen } \\
\text { organisasional } \\
\text { 3.Kepuasan kerja }\end{array}$ & $\begin{array}{l}\text { Deskriptif } \\
\text { kuantitatif }\end{array}$ & $\begin{array}{l}\text { Persamaan: variabel yang } \\
\text { diteliti } \\
\text { Perbedaan: Pada } \\
\text { perusahaan yang diteliti }\end{array}$ \\
\hline \multicolumn{6}{|c|}{$\begin{array}{l}32 \text { Coopetition, Vol X, Nomor 1, Maret 2019, } 27 \text { - } 40 \\
\text { e-ISSN 2615-4978 }\end{array}$} \\
\hline & & - o $0, \ldots . . . . . .$. & & & \\
\hline
\end{tabular}


Setelah mempelajari penelitian terdahulu pada beberapa jurnal seperti pada tabel diatas, maka kelebihan penelitian ini dibandingkan penelitian sebelumnya adalah sebagai berikut :

1. Penelitian terkait pengaruh motivasi dan komitmen organisasional terhadap kepuasan kerja ini terdapat persamaan yaitu pentingnya motivasi dan komitmen organisasional di setiap perusahaan dalam meningkatkan kepuasan kerja karyawan untuk menjalankan kegiatan/aktivitas perusahaan.

2. Penelitian yang terkait pengaruh motivasi dan komitmen organisasional terhadap kepuasan kerja masih sangat terbatas dan belum pernah dilakukan pada industri produksi (khususnya bidang makanan) di Indonesia.

3. Penelitian serupa belum pernah dilaksanakan di bidang makanan dan belum ditemukan baik di berbagai jurnal di Indonesia.

\section{Paradigma Penelitian}

Berdasarkan berbagai kajian pustaka terhadap masing-masing variabel dan hubungan antara variabel yang dibahas sebelumnya, maka dapat dibangun paradigma penelitian yang menghubungkan variabel motivasi individu, komitmen organisasional, dan kepuasan kerja sebagaimana digambarkan dalam gambar berikut :

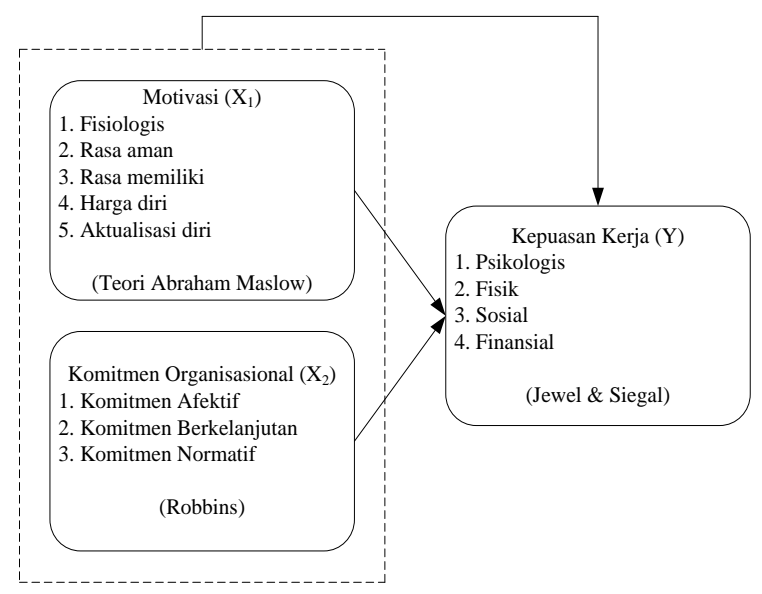

Gambar 3.

Paradigma Penelitian

\section{METODE PENELITIAN}

Penelitian ini termasuk dalam kategori penelitian asosiatif kausal dengan menggunakan pendekatan kuantitatif. Studi kausal merupakan studi dimana peneliti ingin menemukan penyebab dari satu atau lebih masalah (Sekaran, 2007:165). Penelitian ini akan menjelaskan hubungan mempengaruhi dan dipengaruhi dari variabel-variabel yang akan diteliti, yaitu pengaruh variabel motivasi, komitmen organisasional dan kepuasan kerja karyawan. Paradigma penelitian kuantitatif menekankan pada pengujian teori melalui pengukuran variabel penelitian dengan angka dan melakukan analisis data dengan prosedur statistik (Muhyiddin, 2017:26).

Penelitian ini akan dilakukan di Waroeng Spesial Sambal yang beralamat di Jl. Kolonel Ahmad Syam, Sayang jatinangor, Kabupaten Sumedang Jawa Barat 45363. Waktu penelitian ini dilakukan pada bulan Desember 2018 hingga Januari 2019.

Populasi merupakan sekelompok orang, kejadian atau segala sesuatu yang mempunyai karakteristik tertentu (Indriantoro, 2012:115). Populasi dalam penelitian ini adalah 60 karyawan Waroeng Spesial Sambal. Untuk mendapatkan hasil yang akurat, maka peneliti akan mengambil responden seluruh karyawan di Waroeng Spesial Sambal.

Kuesioner yang disebarkan oleh peneliti perlu dilakukan uji coba instrumen terlebih dahulu yang dilakukan untuk mengetahui apakah instrumen yang disusun merupakan hasil yang baik karena baik buruknya instrumen akan berpengaruh pada benar tidaknya data dan menentukan kualitas hasil pada suatu penelitian. Uji coba instrumen dalam penelitian ini adalah: Uji Validitas dan Uji Reliabilitas. Suatu instrumen dikatakan valid jika mampu mengukur apa yang diinginkan dan mengungkapkan data dari variabel yang diteliti secara tepat (Nurhasanah, 2016:82). Sementara itu, reliabilitas merupakan tingkat kepercayaan hasil suatu pengukuran (Rochaety, 2007:49).

Dalam penelitian ini alat yang digunakan untuk analisis data adalah SPSS for window versi 25. SPSS (Statistical Package for Social Sciences) yang berfungsi untuk menganalisis data, melakukan perhitungan statistik baik untuk statistik parametrik maupun nonparametrik dengan basis windows (Ghozali, 20

Adapun teknik analisis dalam penelitian ini Analisis Deskriptif, Uji Asumsi Klasik (Normunutas, Multikolonieritas, Heterokedastisitas) dan Uji Pengaruh (Analisis Regresi Linear, Uji t, Uji F dan Uji $R^{2}$ Koefisien Determinasi)

\section{HASIL DAN PEMBAHASAN}

\section{Gambaran Umum Obyek Penelitian}

Sejarah Berdirinya Waroeng Spesial Sambal (SS) adalah warung makan yang didirikan oleh Yoyok Hery Wahyono pada bulan Agustus tahun 2002. Berawal dari 
kegemaran akan sambal, seorang sarjana teknik kimia UGM rela melepaskan jabatannya sebagai manajer di sebuah perusahaan terkenal untuk memulai membuka usaha warung tenda bersama teman-temannya. Pada tahun 2002 dengan konsep warung tenda, Yoyok Heri Wahyono bersama teman-temannya membuka usaha makanan dengan mengandalkan cita rasa sambal yang pedas. Dengan nama "Waroeng Spesial Sambal (SS)" pria 38 tahun ini berkeinginan memanjakan konsumennya dengan pilihan sambal yang bervariasi. Tidak tanggung-tanggung 28 jenis sambal disiapkan sebagai pendamping lauk pauk dan nasi dengan tingkat kepedasan di atas rata-rata. Jadi, walaupun lauknya sama, tetapi sambalnya bisa berbeda-beda. Perlahan tapi pasti berawal dari warung tenda pinggir jalan kini Waroeng SS telah memiliki lebih dari 55 outlet yang tersebar di kota-kota besar di Indonesia.

Visi Waroeng Spesial Sambal adalah Mensejahterakan keluarga besar SS baik dalam lingkup internal maupun eksternal (karyawan, kemitraan, supplier, pelanggan, dll). Sementara itu, Misi Waroeng Spesial Sambal adalah: Mensejahterakan karyawan, Tetap menjaga nominal jumlah gaji para karyawan, SS memberikan beasiswa kepada karyawannya, SS memberikan pendidikan sampai anak kedua selama wajib belajar, Mensejahterakan Supplier, Mensejahterakan Pelanggan.

\section{Hasil Analisis Deskriptif}

Berikut disajikan hasil analisis deksriptif dari responden untuk penelitian ini.

Tabel 4.

Distribusi Frekuensi Jenis Kelamin

\begin{tabular}{llll}
\hline No. & Jenis Kelamin & Frekuensi & Persentase (\%) \\
\hline 1. & Laki-laki & 23 & $38,3 \%$ \\
2. & Perempuan & 37 & $61,7 \%$ \\
\hline & Total & 60 & $100 \%$
\end{tabular}

Sumber: Data Primer diolah, 2018

Tabel 5.

Karakteristik Karyawan berdasarkan Usia

\begin{tabular}{lll}
\hline Usia & Frekuensi & Persentase \\
\hline 20-25 tahun & 23 & $38,3 \%$ \\
$26-30$ tahun & 29 & $48,3 \%$ \\
$31-40$ tahun & 5 & $8,4 \%$ \\
$>40$ tahun & 3 & $5 \%$ \\
Total & 60 & $100 \%$ \\
\hline
\end{tabular}

Sumber: Data Primer yang diolah 2018

Tabel 6.

Karakteristik Karyawan berdasarkan Pendidikan

\begin{tabular}{lll}
\hline Pendidikan & Frekuensi & Presentase \\
\hline SD & 4 & $6,7 \%$ \\
SMP & 3 & $5 \%$ \\
SMA & 50 & $83,3 \%$ \\
\hline
\end{tabular}

\begin{tabular}{lll}
\hline DIPLOMA & 1 & $1,7 \%$ \\
S1 & 2 & $3,3 \%$ \\
S2 & 0 & 0 \\
TOTAL & 60 & $100 \%$
\end{tabular}

Sumber: Data Primer yang diolah 2018

Tabel 7.

Karakteristik Karyawan berdasarkan Masa Kerja

\begin{tabular}{lcc}
\hline Lama Bekerja & Frekuensi & Presentase \\
\hline$<1$ tahun & 12 & $10 \%$ \\
$1-3$ tahun & 18 & $30 \%$ \\
$>3$ tahun & 30 & $50 \%$ \\
Total & 60 & $\mathbf{1 0 0 \%}$ \\
\hline
\end{tabular}

Sumber: Data Primer yang diolah 2018

Tabel 8.

Karakteristik Karyawan berdasarkan Status Pernikahan

\begin{tabular}{lcc}
\hline Status & Frekuensi & Persentase \\
\hline Menikah & 20 & $33,3 \%$ \\
Lajang & 20 & $66,67 \%$ \\
Total & 60 & $100 \%$ \\
\hline
\end{tabular}

Sumber: Data Primer yang diolah (2018)

\section{Statistik Deskriptif}

Dari perhitungan terhadap ketiga variabel, maka Mean atau rata-rata dari evaluasi tentang pendapat responden adalah sebagai berikut:

Tabel 9.

Descriptive Statistics

\begin{tabular}{ccccc}
\hline No & Variabel & $\begin{array}{c}\text { N (Jumlah } \\
\text { Pertanyaan) }\end{array}$ & Mean & Kategori \\
\hline 1 & $\mathrm{X}_{1}$ & 15 & 3.95 & Baik \\
2 & $\mathrm{X}_{2}$ & 15 & 3.34 & Baik \\
3 & $\mathrm{Y}$ & 15 & 3.75 & Baik \\
\hline
\end{tabular}

Tabel diatas menunjukkan skor rata-rata variabel $\mathrm{Y}$ (Kepuasan Kerja Karyawan) memiliki nilai yang paling tinggi dibandingkan variabel lainnya. Untuk lebih jelas mengenai makna hasil perhitungan statistik deskriptif

34 Coopetition, Vol X, Nomor 1, Maret 2019, 27 - 40 e-ISSN 2615-4978

mengadaptası tentang pengontrolan kualitas (Supranto, 2001) adalah sebagai berikut:

Tabel 10.

Kriteria Penafsiran Kondisi Variabel Penelitian

\begin{tabular}{ll}
\hline Rata-rata Skor & Penafsiran \\
\hline $4,2-5,0$ & Sangat Baik \\
$3,4-4,1$ & Baik \\
\hline
\end{tabular}




\begin{tabular}{ll}
\hline $2,6-3,3$ & Cukup Baik \\
$1,8-2,5$ & Tidak Baik \\
$1,0-1,7$ & Sangat Tidak Baik \\
\hline
\end{tabular}

\section{Hasil Uji Kualitas Data}

\section{Uji Validitas}

Validitas menunjukkan sejauh mana suatu alat pengukur, yaitu kuesioner dapat mengukur apa yang ingin diukur. Jenis validitas yang digunakan dalam penelitian ini adalah Validitas Konstruk, yaitu uji validitas untuk melihat konsistensi antara komponen konstruk yang satu dengan lainnya. Jika semua komponen tersebut konsisten antara yang satu dengan lainnya, maka komponen disebut valid.

Uji signifikansi dilakukan dengan membandingkan nilai $r_{\text {hitung }}$ dengan $r_{\text {tabel }}$ untuk degree of freedom $(\mathrm{df})=n$ - 2, dalam hal ini $\mathrm{n}$ adalah jumlah sampel. Pada penelitian ini, jumlah sampel $(\mathrm{n})=60$ dan besarnya $\mathrm{df}$ dapat dihitung $60-2=58$ dengan $\mathrm{df}=58$ dan alpha $=$ 0.05 di dapat $r_{\text {tabel }}=0.214$. Berikut disajikan hasil dari nilai validitas dari semua variabel.

Tabel 11.

Hasil Uji Validitas Instrumen untuk ke-4 variabel

\begin{tabular}{cccc}
\hline Pertanyaan & \multicolumn{3}{c}{ Corrected Item-Total Correlation } \\
& $\mathbf{X}_{\mathbf{1}}$ & $\mathbf{X}_{\mathbf{2}}$ & $\mathbf{Y}$ \\
\hline 1 & .585 & .527 & 556 \\
2 & .579 & .422 & .573 \\
3 & .546 & .468 & .548 \\
4 & .531 & .415 & .514 \\
5 & .590 & .490 & .560 \\
6 & .545 & .515 & .589 \\
7 & .590 & .586 & .516 \\
8 & .515 & .515 & .522 \\
9 & .595 & .575 & .590 \\
10 & .532 & .412 & .576 \\
11 & .515 & .480 & .525 \\
12 & .527 & .459 & .545 \\
13 & .572 & .486 & .506 \\
14 & .546 & .455 & .514 \\
15 & .562 & .409 & .533 \\
\hline
\end{tabular}

Pernyataan dalam variabel $\mathrm{X}_{1}$ (Motivasi) di atas terdiri dari 15 item. Hasil uji variabel tersebut telah memenuhi kriteria yang disyaratkan, yaitu > 0.214.
Dengan demikian, dapat disimpulkan bahwa butir pernyataan 1 sampai 15 dapat dinyatakan valid dan benar-benar sebagai indikator Motivasi. Karena hasil pada kolom Corrected Item-Total Correlation untuk semua variabel ada di atas 0.214 , maka semua konstruk dianggap valid. Begitupun dengan Variabel Komitmen Organisasional $\left(\mathrm{X}_{2}\right)$ dan Kepuasan Kerja Karyawan (Y) semuanya diatas angka 0.214 yang artinya semua pertanyaan valid.

\section{Uji Reliabilitas}

Reliabilitas adalah alat untuk mengukur suatu kuesioner yang merupakan indikator dari variabel atau konstruk. Suatu kuesioner dikatakan reliabel atau handal jika jawabannya terhadap pernyataan adalah konsisten atau stabil dari waktu ke waktu. Dari Hasil Uji reliabilitas yang dilakukan dapat dinyatakan bahwa semua variabel termasuk kategori reliabel, sebab skornya diatas 0.70. Dengan demikian, instrumen penelitian yang digunakan masing-masing variabel pada penelitian ini dapat dinyatakan variabel dan benar-benar sebagai alat ukur yang handal dan memiliki tingkat kestabilan yang tinggi, dalam arti alat ukur tersebut apabila dilakukan secara berulang, hasil dari pengujian instrumen tersebut akan menunjukkan hasil yang tetap.

Tabel 12.

Hasil Uji Reliabilitas untuk Semua Variabel

\begin{tabular}{lll}
\hline No & Variabel & Skor \\
\hline 1 & $X_{1}$ (Motivasi) & 0.853 \\
2 & $X_{2}$ (Komitmen Organisasional) & 0.890 \\
3 & Y (Kepuasan Kerja Karyawan) & 0.746 \\
\hline
\end{tabular}

\section{UJI ASUMSI KLASIK}

\section{Uji Normalitas}

Uji normalitas bertujuan untuk menguji apakah dalam model regresi, variabel pengganggu atau residual memiliki distribusi normal (Ghozali, 2018:161). Salah satu cara termudah untuk melihat normalitas residual adalah dengan melihat grafik histogram yang membandingkan antara data observasi dengan distribusi yang mendekati distribusi normal (Hozali, 2018:16). Berikut hasil normalitas dengan menggunakan software SPSS. 

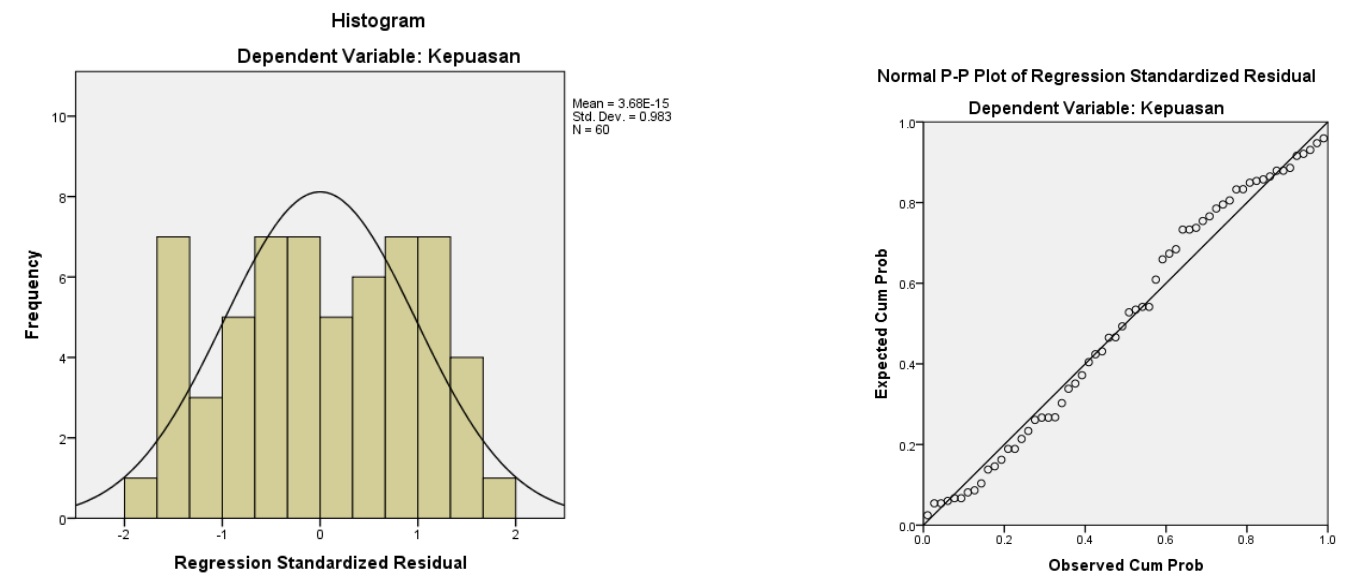

Gambar 3 Histogram dan Diagram Tebar Uji Normalitas

Dengan melihat tampilan grafik histogram maupun grafik normal plot dapat disimpulkan bahwa grafik histogram memberikan pola distribusi yang seimbang (skewness). Sedangkan pada grafik normal plot terlihat titik-titik menyebar disekitar garis diagonal, serta penyebarannya tidak menjauh dari garis diagonal. Kedua grafik ini menunjukkan bahwa model regresi tidak menyalahi asumsi normalitas.

\section{Uji Multikolonieritas}

Uji Multikoloniearitas bertujuan untuk menguji apakah model regresi ditemukan adanya korelasi antar variabel bebas (independen). Model regresi yang baik seharusnya tidak terjadi korelasi di antara variabel independen. Jika variabel independen saling berkorelasi, maka variabel-variabel ini tidak ortogonal. Variabel ortogonal adalah variabel independen yang nilai korelasi antar sesama variabel independen sama dengan nol (Ghozali, 2018:107). Hasil uji multikolonieritas tertera pada tabel berikut ini:

Tabel 13.

Hasil Uji Moltikolonieritas Coefficient Correlations ${ }^{\mathrm{a}}$

\begin{tabular}{|c|c|c|c|}
\hline Model & & Komitmen & Motivasi \\
\hline \multirow[b]{3}{*}{ ces } & Komitmen & 1.000 & -.026 \\
\hline & Motivasi & -.026 & 1.000 \\
\hline & Komitmen & .002 & .000 \\
\hline & Motivasi & .000 & .009 \\
\hline
\end{tabular}

a. Dependent Variable: Kepuasan

Melihat hasil besaran korelasi antar variabel independen tampak bahwa variabel Motivasi yang mempunyai korelasi tinggi dengan variabel Komitmen dengan tingkat korelasi -.026 atau sekitar $2.6 \%$. Oleh karena korelasi ini masih di bawah 95\%, maka dapat dikatakan tidak terjadi multikolonieritas yang serius.

Tabel 14. Hasil Uji Multikolonieritas Coefficients $^{\mathrm{a}}$

\begin{tabular}{llrc}
\hline Model & \multicolumn{2}{c}{$\begin{array}{c}\text { Collinearity Statistics } \\
\text { Tolerance }\end{array}$} & VIF \\
\hline & (Constant) & & \\
1 Motivasi & .999 & 1.001 \\
& Komitmen & .999 & 1.001 \\
\hline
\end{tabular}

a. Dependent Variable: Kepuasan

Hasil perhitungan nilai Tolerance juga menunjukkan tidak ada variabel independen yang memiliki nilai Tolerance kurang dari 0.10 yang berarti tidak ada korelasi antar variabel independen yang nilainya lebih dari $95 \%$. Hasil perhitungan nilai Variance Inflation Factor (VIF) juga menunjukkan hal yang sama tidak ada satu variabel independen yang memiliki nilai VIF lebih dari 10. Jadi, dapat disimpulkan bahwa tidak ada multikolonieritas antar variabel independen dalam model regresi.

\section{Hasil Uji Heteroskedastisitas}

Uji heteroskedastisitas dilakukan untuk menguji terjadinya perbedaan variance residual suatu periode pengamatan ke periode pengamatan yang lain. Cara memprediksi ada tidaknya heteroskedastisitas pada suatu model dapat dilihat dengan pola gambar Scatterplot. 


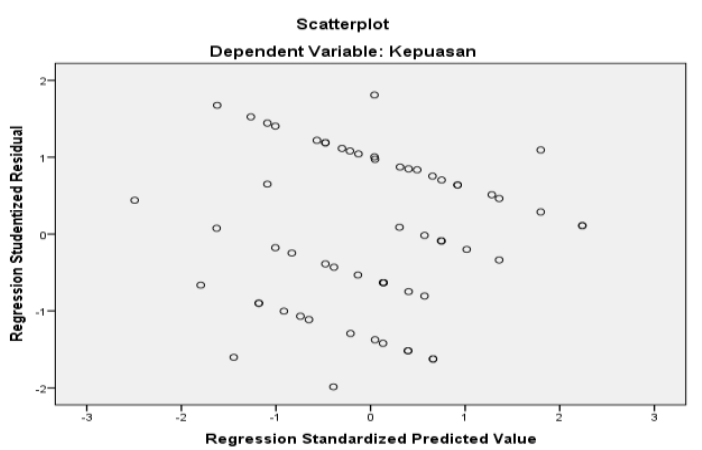

Gambar 4.

Hasil Uji Heteroskedastisitas Scatterplot

Hasil dari gambar diatas, terlihat bahwa titik-titik menyebar di atas dan di bawah angka nol, dan tidak terkumpul hanya di atas atau di bawah saja, titik-titik data tidak membuat pola bergelombang, sehingga dapat disimpulkan bahwa tidak terjadi heteroskedastisitas.

\section{HASIL UJI PENGARUH}

\section{Hasil Analisis Regresi Linear Berganda}

\section{Tabel 15.}

Hasil Uji Analisa Regresi Linear Berganda Coefficients $^{\mathbf{a}}$

\begin{tabular}{llr}
\hline Model & \multicolumn{2}{c}{ Unstandardized Coefficients } \\
& B & \multicolumn{1}{c}{ Std. Error } \\
\hline \multicolumn{1}{l}{ (Constant) } & 52.068 & 6.946 \\
1 Motivasi & .222 & .094 \\
Komitmen & .088 & .049 \\
\hline
\end{tabular}

a. Dependent Variable: Kepuasan

Pada tabel Coefficients, pada kolom B, konstantanya adalah 52.068. Sementara itu, nilai koefisien regresi Motivasi adalah 0.222 ; nilai koefisien regresi Komitmen adalah 0.088. Sehingga berdasarkan tabel di atas, di dapat persamaan regresi berganda yaitu: $\mathrm{Y}=52.068+0.222 \mathrm{X}_{1}+0.088 \mathrm{X}_{2}+\mathrm{e}$.

\section{Hasil Uji t}

Pengujian ini bertujuan untuk menguji tentang setiap variabel bebas (independent) apakah berpengaruh secara signifikan terhadap variabel terikat (dependent) secara parsial dengan $\alpha=0.05$ dan juga tentang penerimaan atau penolakan hipotesis. Maka hasil penelitian yang diperoleh sesuai pada tabel berikut ini:
Tabel 16.

Hasil Uji t Coefficients ${ }^{\mathrm{a}}$

Model $\mathrm{t} \quad$ Sig.

\begin{tabular}{llrr}
\hline & (Constant) & 7.496 & .000 \\
1 & Motivasi & 2.372 & .021 \\
& Komitmen & 1.800 & .077 \\
\hline \multicolumn{2}{l}{ a. Dependent Variable: Kepuasan }
\end{tabular}

Berdasarkan tabel di atas dapat dijelaskan:

1. Nilai $t_{\text {hitung }}$ variabel $X_{1}$ adalah 2.372 dan $t_{\text {tabel }}$ bernilai 2.000 sehingga $2.372>2.000$ dan signifikansi $0.021<0.05$ menandakan signifikan. Dengan demikian, Variabel Motivasi $\left(\mathrm{X}_{1}\right)$ berpengaruh secara signifikan terhadap Kepuasan (Y). Nilai $\mathrm{t}$ positif menunjukkan bahwa variabel Motivasi $\left(\mathrm{X}_{1}\right)$ mempunyai hubungan yang searah dengan variabel Kepuasan (Y).

2. Nilai $t_{\text {hitung }}$ variabel $X_{2}$ adalah 1.800 dan $t_{\text {tabel }}$ bernilai 2.000 sehingga $1.800<2.000$ dan signifikansi $0.077>0.05$ menandakan tidak signifikan. Dengan demikian, Variabel Komitmen $\left(\mathrm{X}_{2}\right)$ tidak berpengaruh dan tidak signifikan terhadap Kepuasan (Y). Nilai t positif menunjukkan bahwa variabel Komitmen $\left(\mathrm{X}_{2}\right)$ mempunyai hubungan yang searah dengan variabel Kepuasan (Y).

\section{Uji F}

Pengujian ini bertujuan untuk menguji apakah semua variabel bebas (independent) yang dimasukkan ke dalam model mempunyai pengaruh secara simultan terhadap variabel terikat (dependent)

Tabel 17.

Hasil Uji F

ANOVA $^{\mathrm{a}}$

\begin{tabular}{llrrrr}
\hline Model & $\begin{array}{c}\text { Sum of } \\
\text { Squares }\end{array}$ & df & $\begin{array}{c}\text { Mean } \\
\text { Square }\end{array}$ & F & Sig. \\
\hline Regression & 15.107 & 2 & 7.554 & 4.550 & $.015^{\text {b }}$ \\
1 Residual & 94.626 & 57 & 1.660 & & \\
Total & 109.733 & 59 & & & \\
\hline
\end{tabular}

a. Dependent Variable: Kepuasan

b. Predictors: (Constant), Komitmen, Motivasi

Sesuai dari tabel di atas menunjukkan bahwa $\mathrm{F}_{\text {hitung }}>\mathrm{F}_{\text {tabel }}=4.550>3.150$ dan sig $=0.015$ (signifikan karena nilainya lebih dari 0.05 ), yang artinya secara simultan variabel $\mathrm{X}_{1}$ dan $\mathrm{X}_{2}$ memiliki pengaruh yang signifikan terhadap Y. 
Uji Koefisien Determinasi $\left(\mathbf{R}^{2}\right)$ berikut:

Hasil penelitian yang diperoleh sesuai pada tabel

\section{Tabel 18}

Hasil Uji Koefisien Determinasi Model Summary ${ }^{\text {b }}$

\begin{tabular}{|c|c|c|c|c|}
\hline Model & $\mathrm{R}$ & $\begin{array}{c}\mathrm{R} \\
\text { Square }\end{array}$ & $\begin{array}{c}\text { Adjusted R } \\
\text { Square }\end{array}$ & $\begin{array}{l}\text { Std. Error of } \\
\text { the Estimate }\end{array}$ \\
\hline & (5/1 & .138 & .107 & 1.288 \\
\hline
\end{tabular}

a. Predictors: (Constant), Komitmen, Motivasi

b. Dependent Variable: Kepuasan

Berdasarkan hasil tabel di atas didapatkan hasil uji Adjusted $R$ Square bernilai 0.107. Hal ini berarti bahwa besarnya kontribusi variabel $\mathrm{X}_{1}$ dan $\mathrm{X}_{2}$ terhadap $\mathrm{Y}$ secara simultan adalah $10.7 \%$ dan selebihnya dipengaruhi oleh faktor lain yang ada di luar model sebesar $89.3 \%$.

\section{PEMBAHASAN}

\section{Pengaruh Motivasi Kerja terhadap Kepuasan kerja Karyawan}

Hasil penelitian ini menunjukkan bahwa terdapat pengaruh positif dan signifikan dengan taraf signifikansi antara motivasi kerja terhadap kepuasan kerja karyawan Waroeng Spesial Sambal. Apabila karyawan memiliki motivasi kerja yang baik maka kepuasan kerja akan meningkat. Di Waroeng Spesial Sambal, profesionalisme sangat dijunjung tinggi oleh perusahaan dan manajemen sangat berusaha untuk menanamkan nilai-nilai tersebut. Berdasarkan hasil angket, indikator psikologis memberikan skor tertinggi yang artinya nilai tersebut diterima baik oleh karyawan sehingga menjadi salah satu faktor meningkatnya kepuasan kerja karyawan Waroeng Spesial Sambal.

\section{Pengaruh Komitmen Organisasional terhadap Kepuasan Kerja Karyawan}

Hasil penelitian ini menunjukkan bahwa komitmen organisasional tidak berpengaruh dan tidak signifikan terhadap kepuasan kerja karyawan Waroeng Spesial Sambal. Dalam hal ini ketika komitmen organiasional yang dialami karyawan rendah maka kepuasan kerja karyawan tidak banyak terpengaruh karena kurangnya kontribusi komitmen organisional. Berdasarkan skor rata-rata jawaban Karyawan dapat diketahui jawaban tertinggi dan terendah. Dengan jawaban tertinggi yang terletak pada indikator "kesediaan berpihak pada perusahaan" berdasarkan pernyataan di kuesioner yang menjelaskan bahwa para karyawan puas dengan yang diberikan perusahaan berdasarkan tanggung jawab pekerjaan yang dibebankan. Apabila karyawan merasakan komitmen organisasionalnya terhadap kepuasan kerja maka akan meningkat.

\section{Pengaruh Motivasi Kerja dan Komitmen Organisasional terhadap Kepuasan Kerja Karyawan}

Hasil penelitian ini menunjukkan bahwa terdapat pengaruh positif dan signifikan antara motivasi kerja dan komitmen organisasional terhadap kepuasan kerja karyawan Waroeng Spesial Sambal. Berdasarkan hasil penelitian, skor tertinggi variabel komitmen organisasional terdapat pada indikator kesediaan untuk berkorban bagi perusahaan, sedangkan skor tertinggi untuk variabel motivasi kerja terletak pada indikator harga diri karyawan. Bila kedua hal terjadi secara bersamaan, dimana karyawan menerima motivasi atas kebutuhan untuk dihormati dan komitmen organisasi terhadap selesai dengan baik pekerjaan yang dilakukannya, sehingga terjadi perasaan yang positif terhadap kepuasan kerja yang dirasakan karyawan. Hal ini sesuai dengan penelitian, Widya paramita, Dianty Larasati, Agung Wahyu handaru (2014), mengemukan bahwa motivasi kerja dan bahwa terdapat pengaruh positif dan signifikan antara motivasi kerja dan komitmen berpengaruh positif dan signifikan terhadap kepuasan kerja karyawan. motivasi kerja dan komitmen berpengaruh diindikasikan memiliki pengaruh yang secara simultan terhadap komitmen organisasional karyawan Waroeng Spesial Sambal. Karyawan yang memiliki motivasi kerja tinggi karena merasa dihargai dan komitmen organisasional yang menghormati hasil kerja karyawannya menyebabkan kepuasan kerja karyawan masih tinggi. Sehingga karyawan melakukan pekerjaannya dengan maksimal dan sesuai dengan peraturan yang sudah ditentukan perusahaan.

\section{SIMPULAN DAN SARAN}

\section{Simpulan}

1. Variabel Motivasi $\left(\mathrm{X}_{1}\right)$ secara parsial berpengaruh secara signifikan terhadap variabel Kepuasan Karyawan (Y).

2. Variabel Komitmen Organisasional $\left(\mathrm{X}_{2}\right)$ secara parsial tidak berpengaruh dan tidak signifikan terhadap variabel Kepuasan Karyawan (Y).

3. Variabel Motivasi $\left(\mathrm{X}_{1}\right)$ dan Komitmen Organisasional $\left(\mathrm{X}_{2}\right)$ secara simultan berpengaruh positif dan signifikan terhadap varianel Kepuasan Karyawan (Y). 
38 Coopetition, Vol X, Nomor 1, Maret 2019, 27 - 40

e-ISSN 2615-4978

\section{Saran}

1. Diharapkan perusahaan dapat mempertahankan nilai-nilai yang ada di dalam organisasi agar penerimaan karyawan terhadap motivasi kerja semakin baik sehingga kepuasan kerja karyawan meningkat.

2. Sebaiknya perusahaan memerhatikan hal yang menyangkut Komitmen Organisasional terutama pada pekerjaan itu sendiri dimana pekerjaan yang dilakukan kurang memberikan komitmen organisasional yang dirasakan oleh karyawan

\section{DAFTAR PUSTAKA}

Allen, N. J, dan Meyer. J. P, (1991). "A Three Component Conceptualization of Organizational Commitment". Human Resource Management Review, Volume 1, Number 1, pages 61-68

Anik, Sri dan Ariffudin, (2003). "Analisis Pengaruh Komitmen Organisasi dan Keterlibatan Kerja Terhadap Hubungan Antara Etika Kerja Islam dengan Sikap Perubahan Organisasi" Jurnal Akuntansi dan Auditing Indonesia . 7(2): 159182

Byrars, Lloyd L, Rue. Leslie W. (2004). Human Resource Management 7/e. Indiana University. McGraw-Hill.

Changgriawan, Garry Surya. (2017). Pengaruh Kepuasan Kerja dan Motivasi Kerja Terhadap Kinerja Karyawan di One Way Production. AGORA Vol. 5, No. 3. Retrieved from http://publication.petra.ac.id/index.php/manajeme n-bisnis/article/view/6095/5593

Daft, Richard L. (2006). Manajemen, Edisi 6. Jakarta: Salemba Empat

Dessler, Gary. (2013). Manajemen Sumber Daya Manusia. Jilid 1. Jakarta: Prenhalindo.

(2013). Manajemen Sumber Daya Manusia. Jilid 2. Jakarta: Prenhalindo.

Ghozali, Imam. (2018). Aplikasi Analisis Multivariate dengan Program IBM SPSS 25 Edisi 9. Semarang: Badan Penerbit Universitas Diponegoro

Griffin, Ricky W. (2004). Manajemen, Edisi Kesepuluh. Jakarta: Erlangga.
Indriantoro, Nur dan Supomo. (2014). Metodologi Penelitian Bisnis untuk Akuntansi \& Manajemen. Yogyakarta: BPFE

Jewell, L. N. \& Siegall, M., (1998). Psikologi Industri/Organisasi Modern: Psikologi Penerapan untuk Memecahkan Berbagai Masalah di Tempat Kerja, Perusahaan, Industri, dan Organisasi, ed-2. Jakarta: Arcan

Luthans, Fred. 2006. Perilaku organisasi Edisi. 10. Yogyakarta: penerbit Andi.

Meyer, P. John., and Herscovitch, Lynne. (2001). Commitment in the Workplace Toward a General Model. Human resource management review, 11, 299-326

Muhyiddin et al., (2017). Metodologi Penelitian Ekonomi dan Sosial. Jakarta: Salemba Empat

Noe, Raymond A., Hollenbeck, John R., Gerhart, Barry., \& Wright, Patrick M. (2010). Manajemen Sumber Daya Manusia: Mencapai Keunggulan Bersaing. (Edisi 6, Jilid 1). Jakarta: Salemba Empat.

(2010). Manajemen Sumber Daya Manusia: Mencapai Keunggulan Bersaing. (Edisi 6, Jilid 2). Jakarta: Salemba Empat.

Nurhasanah, Siti. (2016). Praktikum Statistika 1 untuk Ekonomi dan Bisnis Buku 1. Jakarta Selatan: Salemba Empat

(2016). Praktikum Statistika 1 untuk Ekonomi dan Bisnis Buku 2. Jakarta Selatan: Salemba Empat

Paramita, W., Larasati, D., \& Handaru, A. (2014, April 30). Pengaruh Motivasi dan Komitmen Organisasional Terhadap Kepuasan Kerja pada Pegawai Tata Usaha (Studi pada Tujuh Fakultas di Universitas Negeri Jakarta). JRMSI - Jurnal Riset Manajemen Sains Indonesia, 5(1), 123-146. Retrieved from http://journal.unj.ac.id/unj/index.php/jrmsi/article /view/798

Pratiwi, Putri. 2012.' Pengaruh Budaya Organisasi dan Pemberdayaan Terhadap Kinerja dalam Meningkatkan Kinerja." Tesis Universitas Mahasaraswat, Denpasar. 
Rimapulaeng, Kenly dan Jantje L Sepang. (2014). "Motivasi Kerja, Komitmen Karyawan dan Budaya Organisasi, Pengaruhnya Terhadap Komitmen Organisasional di PT Gudang Garam Manado." Jurnal EMBA Vol.2 No.3.Hlm.137148

Rivai, Veithzal. (2011). Manajemen Sumber Daya Manusia untuk Perusahaan: dari Teori ke Praktik. Jakarta : Raja Grafindo Persada

Robbins, Stehen P, dan Timothy A Judge, (2008). Perilaku Organisasi Edisi 12 Jilid 1. Jakarta: Salemba Empat

(2008). Perilaku Organisasi Edisi 12 Jilid 2. Jakarta: Salemba Empat

(2015). Organizational Behavior. Edisi 16. USA: Pearson

Rochaety E, dkk. (2007). Metodologi Penelitian Bisnis: dengan Aplikasi SPSS, Edisi Pertama. Jakarta: Penerbit Mitra Wacana Media

Sadili, Samsudin. (2006). Manajemen Sumber Daya Manusia. Bandung: Pustaka Setia

Schuler, Randall S. dan Jakson, Susan E. (2000). Manajemen Sumber Daya Manusia Menghadapi Abad Ke-21. (Terjemahan: Nurdin Sobary dan Dwi Kartini Yahya). Jakarta: Erlangga

Sekaran, Uma. (2007). Metodologi Penelitian untuk Bisnis Edisi 4 Buku 1. Jakarta: Salemba Empat

(2007). Metodologi Penelitian untuk Bisnis Edisi 4 Buku 2. Jakarta: Salemba Empat

Widari, Intan Maharani dan Wibawa, Made Artha. (2017). Pengaruh Komitmen Organisasional dan Dukungan Tim Kerja Terhadap Representasi Eksternal Positif Karyawan di Tempat Kerja. EJurnal Manajemen Unud, Vol. 6, No. 7, 2017: 3457-3484 ISSN : 2302-8912 
40 Coopetition, Vol X, Nomor 1, Maret 2019, 27 - 40 e-ISSN 2615-4978 